\title{
The Effect of Combination of Picloram and Bap on the Calculation of Clean Plants (Postogemon cablin Benth)
}

\author{
Deasy Monica Latif ${ }^{1}$, Warnita ${ }^{2}$, Renni Mayerni ${ }^{3}$ \\ ${ }^{1}$ Department of Agronomy, Faculty of Agriculture, Andalas University, Padang - West Sumatera, INDONESIA \\ Email: desilatif19@gmail.com \\ ${ }^{2}$ Department of Agrotechnology Faculty of Agriculture, Andalas University, Padang - West Sumatera, INDONESIA \\ Email: warnita_irnu@yahoo.com \\ ${ }^{3}$ Department of Agrotechnology Faculty of Agriculture, Andalas University,Padang West Sumatera INDONESIA \\ Email: prof.renimayerni@gmail.com
}

\begin{abstract}
This study aims to determine the best Picloram and BAP concentrations in InVitro patchouli callus formation. This experiment was conducted in November 2018 to January 2019 at the Tissue Culture Laboratory, Faculty of Agriculture, Andalas University, Padang. This study used an experimental method with Completely Randomized Design (CRD) consisting of two factors. The first factor was the administration of Picloram concentration with 5 levels of treatment and the second factor was the administration of BAP concentrations with 5 levels of treatment. This experiment consisted of: This experiment consisted of Factor I: Picloram (A) Without Picloram (A1), Concentration of 1 $m g$ / L (A2), Concentration of $2 m g / L$ (A3), Concentration of $3 \mathrm{mg} / \mathrm{L}(\mathrm{A4})$, Concentration of $4 \mathrm{mg} / \mathrm{L}$ (A5), Factor II: Concentration of BAP $(S)$ Without BAP (S1), Concentration of $0.5 \mathrm{mg} / L(S 2)$, Concentration of 1 $m g$ / L (S3), Concentration of $1.5 \mathrm{mg} / \mathrm{L}$ (S4) Concentration $2 \mathrm{mg} / \mathrm{L}(\mathrm{S} 5)$. The data obtained were analyzed using the F test at the level of 5\%, if F count is greater than $F$ table then the analysis is continued with the DMNRT test at the level of 5\%. From the results of the study showed that the concentration of picloram had a significant effect on the growth of patchouli callus with an average callus appearance of 7 HST and percentage (\%) of explants growing up to $100 \%$. High picloram concentration did not significantly affect callus growth, 2 $m g / l$ picloram + BAP concentration did not produce callus.
\end{abstract}

Keywords- Patchouli (Pegestemon cablin Benth), Picloram, BAP, Tissue Culture.

\section{INTRODUCTION}

Patchouli plant (Pogostemon cablin Benth.) Is one of the important export commodities in Indonesia because $90 \%$ of the world's needs for patchouli oil are supplied by
Indonesia. Patchouli oil is widely used in the perfume, pharmaceutical, food and aroma therapy industries containing essential oils (Mangun, 2005 in Hatta et al., 2008). Patchouly oil is obtained from the distillation of patchouli leaves. Indonesian patchouli oil exports amounted to $800-1,500$ tons worth US \$ 18-53 million (Mustika and Nuryani, 2006). Patchouli oil exports reached 700 to 1,500 tons, with a foreign exchange value of US \$ 14 to 30 million (Sulfiani, et al., 1998). Based on data from the National Export Development Agency, in Indonesia there are 14 production centers spread in four provinces. Patchouli oil is the largest product for essential oils and its use in the world shows an increasing trend. It can be said that until now there have not been any products, both natural and synthetic, that can replace patchouli oil in its position as fixative. BPS export data shows that the contribution of patchouli oil to the export income of essential oils is around $60 \%$, vetiver oil (Vetiner oil) is around $12.47 \%$, citronella oil (Citronella oil) is around $6.89 \%$, and ginger oil (Ginger oil) around $2.74 \%$ (Krismawati, 2005). Until now $90 \%$ of the world's patchouli oil needs, equivalent to almost 2000 tons, are supplied from Indonesia. West Sumatra is the largest patchouli oil producer in Indonesia. In 2017 the area of West Sumatra patchouli plant reached 2,762 ha with a production of 200 tons (Directorate General of Plantation Indonesia, 2017).There are three types of patchouli in Indonesia, namely Pogostemon cablin Benth, P.hortensis Baker, and P. heyneanus Bent. The last two types of patchouli are rarely cultivated, because of the low yield and quality of oil, so that commercially is no longer profitable. Pogostemon cablin Benth is patchouli which naturally cannot flower in Indonesia. West Sumatra as one of the centers marked by the extent of patchouli cultivation by farming communities is 2765 ha with the main production center in West Pasaman with an area of 
1,496 ha, Mentawai islands 783 ha and the area of 237 ha (plantation statistics 2015). In addition to the three central areas of patchouli cultivation there are still several other areas in West Sumatra that can also develop patchouli plants and new areas of development of patchouli plants.

Patchouli potential in West Sumatra, especially in West Pasaman Regency, there are many patchouli plants that have been cultivated by the community since long ago. This is evidenced by the presence of local clones in each District. From 11 Subdistricts in West Pasaman there are 6 Subdistricts which have been found Nilam clones, including (1) Kinali Subdistrict (ai maruok clone), (2) Pasaman District (rimbo binuang and bukik nilam clones), (3) Talamau District ( tombang clone), (4) Gunung Tuleh District (tanjung durian clone), (5) Lembah Melintang District (situ clone), and in (6) Koto Balinka District (lubuk godang clone) (Hidayat, 2017) Lately it has been known that there was a decrease in patchouli oil production which was partly due to low genetic quality, simple cultivation technology, the development of various diseases, and improper harvesting and post-harvest techniques (Nuryani 2006). According to Kadir (2011) the low genetic variability causes a narrow genetic diversity and difficulty in forming new clones. Until now the patchouli superior varieties that have been released are still very limited. One of the efforts to improve the quality of this oil can be done by using superior seeds that have the desired oil quality, but the availability of the number of superior seeds available is still limited (Directorate General of Plantation, 2007). One alternative for the rapid supply of seeds is by using vitro propagation techniques or tissue culture. Plant tis sue culture is a technique to develop aseptic and accentic parts of plants in vitro on culture media containing complete nutrients and controlled conditions for specific purposes. Tissue culture is based on the theory of cell totipotence which states that every living plant cell has complete genetic information and physiological devices to grow and develop into intact plants if the conditions are appropriate. Plant propagation in tissue culture can produce large quantities of plant seeds in a short time so it is more economical, does not require a large area, can be carried out throughout the year without depending on the season, and the seeds produced are healthier (Yusnita, 2015). The success in in vitro propagation is determined by many factors including types of explants and growth regulators (Swamy et al. 2010; Hua et al. 2014; Norrizah et al. 2012).These growth regulating substances play a role in stimulating and increasing the growth and development of cells, tissues, and plant organs in the direction of certain differentiations. The use of growth regulating substances at the right concentration can stimulate explant growth, especially the formation of roots, shoots, and callus. Plant growth regulators play an important role in controlling biological processes in plant tissues (Davies, 1995; Gaba, 2005). Its role, among others, regulates the growth rate of each network and integrates these parts in order to produce the form we know as plants. The activity of growth regulators in growth depends on species, chemical structure, concentration, plant genotypes and plant physiology phases (Satyavathi et al., 2004; George, 1993; Dodds and Roberts, 1982). In the process of forming organs such as shoots or roots there is an interaction between exogenous growth regulators added to the media with endogenous growth regulators produced by plant tissue (Winata 1987). Addition of auxin in a larger and more stable amount tends to cause callus growth from explants and inhibit the regeneration of plant shoots (Wetherell, 1982) while cytokinins and auxin combined with their main activity is to encourage cell division (Karjadi and Buchory, 2008). Picloram is one of the synthetic auxin which is widely used for callus induction (Aprisa, 2012). Picloram is more effective in increasing callus induction if compared to growth regulator $2.4 \mathrm{D}$ (Chernova, et.al, 1975). Tu et al. (2001) added that picloram in low concentrations can stimulate RNA synthesis and DNA replication in controlling cell division and growth. while BAP is synthetic cytokinin which has a higher activity compared to natural cytokines (Santoso and Nursandi, 2003). Cytokinin (BAP) which is balanced with auxin (Picloram) can cause callus growth (Abidin, 1985). According to Litz and Gray, 1995 the use of a combination of cytokinin (BAP) and auxin (Picloram) will improve the induction process. Based on the exposure, the research on the use of various concentrations of picloram and cytokinin (BAP) for the best callus formation and can provide information about the announcement of the composition of picloram and cytokinin (BAP) which is most suitable for the formation of (Pogostemon cablin Benth).

\section{MATERIALS AND METHODS}

This experiment was conducted in November 2018 until January 2019 at the Network Culture Laboratory, Faculty of Agriculture, Andalas University, Padang. The materials used were situ clone patchouli plants (Jorong Situak in Lembah Melintang District) (Appendix 2), Picloram, BAP (Benzyl Amino Purine), MS media (Murashige and Skoog), agar agar (7 g / L), fungicide ( Dhitane M45) $2 \mathrm{~g}$ / L, bactericidal (Agrept20WP) $2 \mathrm{~g} / \mathrm{L}$, antibiotics (Streptomycin) $0.05 \mathrm{~g} / \mathrm{L}$, Tween 20, sterile distilled water, 70\% alcohol and 96\%, 3\% sucrose, HCL $1 \mathrm{~mol} / \mathrm{L}$ , $1 \mathrm{~mol} / \mathrm{L} \mathrm{NaOH}, \mathrm{pH}$ meter, plastic, rubber band, plastic wrap, tissue, spritus, masking tape (clear tape), disinfectant (formalin), aluminum foil, micropipette tips, 
$\mathrm{pH}$ paper, and label paper. The tools used in this experiment are Laminar Air Flow Cabinet (LAFC), autoclaves, analytical scales, hot plate magnetic stirers, ovens, scalpell blades, tweezers, erlenmeyer $1000 \mathrm{~mL}, 50$ $\mathrm{mL}$ cup cups, culture bottles, bunsen, petridisk, measuring cups $10 \mathrm{~mL}$, glass bottles, culture rack, micropipette, Color chart, handsprayer stationery, camera. This study used an experimental method with Completely Randomized Design (CRD) consisting of two factors. The first factor was the administration of Picloram concentration with 5 levels of treatment and the second factor was the administration of BAP concentrations with 5 levels of treatment. This experiment consisted of: This experiment consisted of Factor I: Picloram (A) Without Picloram (A1), Concentration of $1 \mathrm{mg} / \mathrm{L}$ (A2), Concentration of $2 \mathrm{mg} / \mathrm{L}$ (A3), Concentration of $3 \mathrm{mg} / \mathrm{L}$ (A4), Concentration of $4 \mathrm{mg} / \mathrm{L}$ (A5), Factor II: Concentration of BAP (S) Without BAP (S1), Concentration of $0.5 \mathrm{mg} / \mathrm{L}$ (S2), Concentration of $1 \mathrm{mg} /$ L (S3), Concentration of $1.5 \mathrm{mg} / \mathrm{L}$ (S4) Concentration 2 $\mathrm{mg} / \mathrm{L}$ (S5). Each treatment was repeated 3 times so that there were 75 bottles of explants. The data obtained were analyzed using the $\mathrm{F}$ test at the level of $5 \%$, if $\mathrm{F}$ count is greater than F table then the analysis is continued with the DMNRT test at the level of $5 \%$.

\section{RESULTS AND DISCUSSIONS}

\section{Appearing Callus}

This research was carried out by giving auxin group Picatinam ZPT and cytokinin group namely BAP with 25 combinations of treatments using shoot explants, with explants position after cutting, the position of the leaf bone facing upward and the remaining part of the leaf slightly removed to accelerate callus formation process. Callus is a cell that has not been differentiated formed from slices of explants (Hendaryono daan Wijayani, 1994). Table 1 shows the diversity of patchouli plant callus time can be seen from the average callus emergence on the combination treatment of picloram concentration without BAP concentration and the treatment of picloram concentration with a concentration of BAP $2 \mathrm{mg} / 1$ that is at $7 \mathrm{HST}$, followed by concentration treatment picloram + BAP $1 \mathrm{mg} / 1$, treatment of picloram + BAP concentration of $1.5 \mathrm{mg} / 1$ while for treatment $2 \mathrm{mg} / 1$ Picloram + BAP concentration does not occur in callus formation. According to Gunawan (1987) the contrast of different ZPTs gave a different response to callus induction. Slow and fast formation or formation of callus is influenced by endogenous hormones, it is thought that the patchouli plant of endogenous BAP hormone can not meet the needs of the explants so that the callus formed only at the high BAP. Callus growth is influenced by several factors related to explants such as the availability of energy sources, the environment and Growth Regulatory Substances, especially the balance between cytokinin and auxin hormones in tissue culture (sumardi, 1996). In line with research by Wattimena et al. (1992) in the in vitro structure, morphogenesis of explants always depends on the interaction between auxin and cytokinin given and contained in explants strengthened by the study of Wulandari et al. (2004) that the concentration of auxin an cytokinin often controls the amount of growth and form of culture, both in callus growth and organogenesis. Callus growth in explants increases when leaf bones containing file / tissue transporter, this is due to the transport network can be more nutrient when compared to leaf leaves that do not have a transport network (Nurwahyuni) in Intias (2012). Callus growth is influenced by several factors related to explants such as the availability of energy sources, the environment and growth regulators, especially the balance between cytokinins and auxin in tissue culture (Sumardi, 1996). Wattimena et al. (1992) in in vitro culture, morphogenesis of explants always depends on the interactions between auxin and cytokinin given and those contained in explants. The concentrations of these two ZPTs often control the shape and amount of growth of a culture, both in callus growth and organogenesis (Wulandari et al., 2004). Callus can emerge from the former part of the explan at the time of cutting the segment, which is also a process of opening, as in the study of Marlin et al. (2012) that callus formation is caused by stimulation of injured explant tissue to cover existing wounds, resulting from the formation of callus causes the cell wall to change direction, where some protoplasts flow outward. In line with the research of George and Sherrington (1984), which states that cell division that leads to the formation of callus occurs from the response to injury and the supply of natural or artificial hormones from the outside into the explants. Can be seen in figure 2 below: After the explants experience changes by sensitizing the observations then the callus begins to appear, the callus does not appear throughout all parts of the plant. in line with the research conducted by Gunawan (1988), that cell division does not occur in all cells in the original tissue, but only cells that actively divide continuously. The initiation of cell division is only limited to the outer layer of tissue can be caused by higher oxygen availability, $\mathrm{CO} 2$ gas release, more nutrient availability, phenolic inhibitors that evaporate faster, and light.

\section{Percentage $(\%)$ of life explants}

Percentage $(\%)$ of living explants is a condition in which explants planted in the media grow. According to Fauzan et al. (2004) eksplan life is characterized by fresh 
explants, brightly colored and not experiencing browning or decay. All treatment studies of the percentage $(\%)$ of life explants in patchouli plants can be seen in table 2 as follows: Table 2. Shows the percentage (\%) of live explants that of the 25 combinations of picloram and BAP treatments in patchouli plants there are 22 live explant treatments. Treatment Concentration of $1 \mathrm{mg} / 1$ picloram + concentration of $0.5 \mathrm{mg} / 1$ and $1 \mathrm{mg} / 1 \mathrm{BAP}$, and concentration of $0.5 \mathrm{mg} / 1$ picloram $+1 \mathrm{mg} / 1$ BAP produced explants growing $100 \%$ meaning that there was an effect between the treatment of picloram and BAP concentrations to the percentage $(\%)$ of explant growth. At a concentration of $2 \mathrm{mg} / \mathrm{l}$ picloram + BAP concentration there is no explant that grows, meaning that there is no effect on patchouli explant growth in line with the statement of Hendaryono and Wijayani (1994), namely at high levels, auxin is more inhibiting than stimulating growth. Picloram is not a growth regulator for explants but rather becomes a herbicide. This is in accordance with the opinion of Tu, et. Al. (2001) that picloram with high concentration can inhibit cell division and cell growth. From the table above, it can be seen that the combination of $2 \mathrm{mg} / 1$ picloram and BAP concentration has not been able to increase the growth power of patchouli explants.

\section{Callus Texture}

Callus texture is a marker used to assess the quality of a callus. Callus texture can be divided into three types, namely compact (non friable), intermediate and crumb (friable) (Andrayani, 2010). Callus is good for use as a secondary metabolite-producing material that has a compact (non friable) texture. Compact callus texture is considered good because it can accumulate more secondary metabolites (Indah and Dini, 2013). Callus which has a compact texture generally has small cell size with solid cytoplasm, large nucleus, and has a lot of wheat starch (carbohydrate) according to Dodd (1993) in Ariati (2012). Andri (2012) states that compact callus has a nodule-like structure. Nodules are proembryonic and can be used as an inoculum for induction as a somatic embryo. According to Sitorus, (2011) crumb callus is a callus that grows apart into parts that are small, easily separated, and contain lots of water. Callus formation is influenced by certain substances in the medium such as growth regulators. $2.4 \mathrm{D}$ concentration and high yeast extract will produce friable textured callus (Rahayu et al., 2003). The results of observations about callus texture in this study can be seen in table 3 below: Can be seen from the table of observations of the callus texture of each treatment on patchouli explant growth has a compact texture and crumbs. In line with the study of Pieril (1987) stated that the texture of the callus, which is compact to weaker, depends on the type of plant used, the composition of nutrient media, regulating growth temperature and environmental conditions of the culture. In the study conducted by Lim et.al (2009), the combination treatment of growth regulator $3 \mathrm{mg} / 1$ picloram and various cytokinin concentrations on Ocimum sanctum leaves produced compact texture callus. This can occur because the administration of high picloram concentrations can produce crumb callus. In line with the statement of Chernova et al. (1975) picloram has almost the same properties as 2.4 D. Rahayu (2003) states that a high concentration of $2.4 \mathrm{D}$ will produce friable textured callus. Below this is the callus texture image after being identified in the observation of 3MST.

\section{FIGURES AND TABLES}

Table.1: When Appears Callus of Patchouli Plants at Various Treatments (HST)

\begin{tabular}{clllllll}
\hline \multirow{2}{*}{ Treatment } & \multicolumn{7}{c}{ BAP concentration (mg/l) } \\
\cline { 2 - 8 } & 0 & 0 & 0,5 & 1 & 1,5 & 2 & Average \\
\hline \multirow{2}{*}{ Picloram } & 0,5 & 7 & 9 & 9 & 7 & 7 & 7.8 \\
concentration & 1 & 7 & 8 & 12 & 10 & 7 & 8.8 \\
(mg/l) & 1,5 & 7 & 10 & 7 & 7 & 7 & 7.6 \\
& 2 & 0 & 0 & 0 & 0 & 0 & 0 \\
\hline
\end{tabular}

The numbers in the column above are not significantly different according to the $\mathrm{F}$ test at the level of $5 \%$

Table.2: Percentage (\%) of explants of patchouli plant life at various treatments

\begin{tabular}{cllllll}
\hline \multirow{2}{*}{ Treatment } & \multicolumn{6}{c}{ BAP concentration (mg/l) } \\
\cline { 2 - 7 } & 0 & 66.6 & 66.67 & 66.67 & 66.6 & 33.33 \\
& & 7 & & & 7 & \\
& 0, & 33.3 & 33.33 & 100.0 & 33.3 & 33.33 \\
Picloram & 5 & 3 & & 0 & 3 & \\
concentrati & 1 & - & 100.0 & 100.0 & 66.6 & 33.33 \\
on (mg/l) & & & 0 & 0 & 7 & \\
& 1, & - & 66.67 & 66.67 & 33.3 & 100.0 \\
& 5 & & & & 3 & 0 \\
& 2 & - & - & 0 & 0 & 0 \\
\hline
\end{tabular}

The numbers in the column above are not significantly different according to the $\mathrm{F}$ test at the level of $5 \%$

Table.3: Results of Observation of Callus Texture at 4 MST at Various Treatments

\begin{tabular}{lcc}
\hline $\begin{array}{c}\text { Sample } \\
\text { Code }\end{array}$ & $\begin{array}{c}\text { Picloram and BAP } \\
\text { combination }\end{array}$ & $\begin{array}{c}\text { Forming } \\
\text { Callus } \\
(\boldsymbol{\%})\end{array}$ \\
\hline $\mathrm{A}_{1} \mathrm{~S}_{1}$ & $0 \mathrm{mg} / \mathrm{l} \mathrm{PIC}+0 \mathrm{mg} / \mathrm{l} \mathrm{BAP}$ & - \\
\hline
\end{tabular}




\begin{tabular}{|c|c|c|c|c|c|}
\hline $\mathrm{A}_{1} \mathrm{~S}_{2}$ & $0 \mathrm{mg} / \mathrm{l} \mathrm{PIC}+0.5 \mathrm{mg} / \mathrm{l} \mathrm{BAP}$ & - & $\mathrm{A}_{3} \mathrm{~S}_{3}$ & $1 \mathrm{mg} / \mathrm{l} \mathrm{PIC}+1 \mathrm{mg} / \mathrm{l} \mathrm{BAP}$ & - \\
\hline $\mathrm{A}_{1} \mathrm{~S}_{3}$ & $0 \mathrm{mg} / \mathrm{l} \mathrm{PIC}+1 \mathrm{mg} / \mathrm{l} \mathrm{BAP}$ & Crumb & $\mathrm{A}_{3} \mathrm{~S}_{4}$ & $1 \mathrm{mg} / \mathrm{l} \mathrm{PIC}+1.5 \mathrm{mg} / \mathrm{l} \mathrm{BAP}$ & - \\
\hline $\mathrm{A}_{1} \mathrm{~S}_{4}$ & $0 \mathrm{mg} / \mathrm{l} \mathrm{PIC}+1.5 \mathrm{mg} / \mathrm{l} \mathrm{BAP}$ & Crumb & $\mathrm{A}_{3} \mathrm{~S}_{5}$ & $1 \mathrm{mg} / \mathrm{l} \mathrm{PIC}+2 \mathrm{mg} / \mathrm{l} \mathrm{BAP}$ & Compact \\
\hline $\mathrm{A}_{1} \mathrm{~S}_{5}$ & $0 \mathrm{mg} / \mathrm{l} \mathrm{PIC}+2 \mathrm{mg} / \mathrm{l} \mathrm{BAP}$ & Compact & $\mathrm{A}_{4} \mathrm{~S}_{1}$ & $1.5 \mathrm{mg} / \mathrm{l} \mathrm{PIC}+0 \mathrm{mg} / \mathrm{l} \mathrm{BAP}$ & Compact \\
\hline $\mathrm{A}_{2} \mathrm{~S}_{1}$ & $0.5 \mathrm{mg} / \mathrm{l} \mathrm{PIC}+0 \mathrm{mg} / \mathrm{l} \mathrm{BAP}$ & Compact & $\mathrm{A}_{4} \mathrm{~S}_{2}$ & $1.5 \mathrm{mg} / \mathrm{l} \mathrm{PIC}+0.5 \mathrm{mg} / \mathrm{l} \mathrm{BAP}$ & Crumb \\
\hline $\mathrm{A}_{2} \mathrm{~S}_{2}$ & $0.5 \mathrm{mg} / 1 \mathrm{PIC}+0.5 \mathrm{mg} / 1 \mathrm{BAP}$ & Crumb & $\mathrm{A}_{4} \mathrm{~S}_{3}$ & $1.5 \mathrm{mg} / \mathrm{l} \mathrm{PIC}+1 \mathrm{mg} / \mathrm{l} \mathrm{BAP}$ & Crumb \\
\hline $\mathrm{A}_{2} \mathrm{~S}_{3}$ & $0.5 \mathrm{mg} / \mathrm{l} \mathrm{PIC}+1 \mathrm{mg} / \mathrm{l} \mathrm{BAP}$ & - & $\mathrm{A}_{4} \mathrm{~S}_{4}$ & $1.5 \mathrm{mg} / \mathrm{l} \mathrm{PIC}+1.5 \mathrm{mg} / \mathrm{l} \mathrm{BAP}$ & - \\
\hline $\mathrm{A}_{2} \mathrm{~S}_{4}$ & $0.5 \mathrm{mg} / 1 \mathrm{PIC}+1.5 \mathrm{mg} / \mathrm{l} \mathrm{BAP}$ & - & $\mathrm{A}_{4} \mathrm{~S}_{5}$ & $1.5 \mathrm{mg} / \mathrm{l} \mathrm{PIC}+2 \mathrm{mg} / \mathrm{l} \mathrm{BAP}$ & - \\
\hline $\mathrm{A}_{2} \mathrm{~S}_{5}$ & $0.5 \mathrm{mg} / 1 \mathrm{PIC}+2 \mathrm{mg} / 1 \mathrm{BAP}$ & - & $\mathrm{A}_{5} \mathrm{~S}_{1}$ & $2 \mathrm{mg} / \mathrm{l} \mathrm{PIC}+0 \mathrm{mg} / \mathrm{l} \mathrm{BAP}$ & - \\
\hline $\mathrm{A}_{3} \mathrm{~S}_{1}$ & $1 \mathrm{mg} / \mathrm{l} \mathrm{PIC}+0 \mathrm{mg} / \mathrm{l} \mathrm{BAP}$ & Compact & $\mathrm{A}_{5} \mathrm{~S}_{2}$ & $2 \mathrm{mg} / \mathrm{l} \mathrm{PIC}+0.5 \mathrm{mg} / \mathrm{l} \mathrm{BAP}$ & Compact \\
\hline $\mathrm{A}_{3} \mathrm{~S}_{2}$ & $1 \mathrm{mg} / 1 \mathrm{PIC}+0.5 \mathrm{mg} / 1 \mathrm{BAP}$ & - & & & \\
\hline
\end{tabular}

Figure 1: Changes in explants into callus

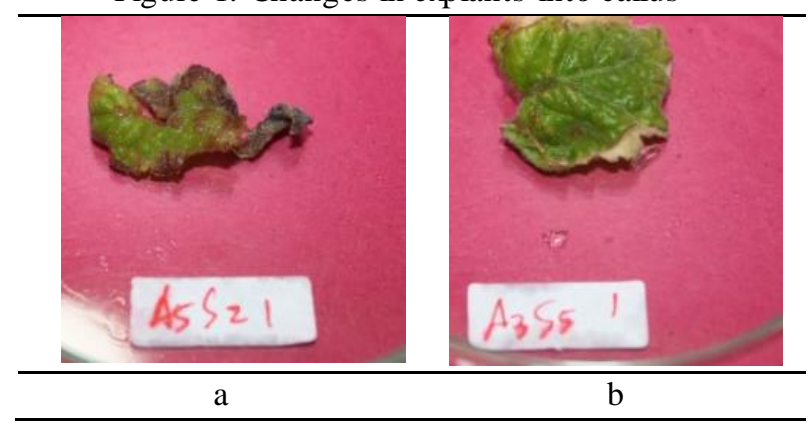

Figure 1. Changes in explants into callus (a), Callus Nilam with the treatment of $1 \mathrm{mg} / \mathrm{L} 2 \mathrm{mg} / \mathrm{l} P I C+0.5 \mathrm{mg} / \mathrm{l} \mathrm{BAP;}(\mathrm{b})$, Callus Nilam with the Treatment of A3S5 $1 \mathrm{mg} / \mathrm{l} P I C+2 \mathrm{mg} / \mathrm{l} \mathrm{BAP}$

\section{CONCLUSION}

Based on the results of research on it can be concluded that: The concentration of picloram has a significant effect on the growth of patchouli callus with an average callus appearance of $7 \mathrm{HST}$ and percentage (\%) of explants growing to $100 \%$. High picloram concentration did not significantly affect callus growth, $2 \mathrm{mg} / 1$ picloram + BAP concentration did not produce callus. Suggestions that can be conveyed related to this research are that further research is needed and with a longer observation time, so that patchouli callus growth can be more clearly seen.

\section{REFERENCES}

[1] Abidin, Z. 1983. Basics of Knowledge About Growth Regulating Substances. Bandung: Angkasa.

[2] Aisyah, Y.2010. Characterization of Patchouli Oil (Pogostemon cablinBenth) and Increased Level of Patchouli Alcohold in Patchouli Oil Using Cellulose Acetate Membranes and Fractionation Distillation. Dissertation. Faculty of Agricultural Technology, Gadjah Mada University, Yogyakarta.

[3] Andaryani, S. 2010. Study of the Use of Various BAP and 2,4-D Concentrations in Induction of Jatropha CurcasL Callus (Jatropha Curcas L). Thesis. Faperta Sebelas Maret University. Surakarta
[4] Aprisa, R. 2012. Embryogenic Callus Induction of Two Corn Mutant Genotypes (Zea maysL.) In MS and N6 Basic Media. Essay. Department of Agronomy and Horticulture, Faculty of Agriculture, Agricultural Institute Bogor.

[5] Ardiana, D.W. 2009. The Technique of Giving Benzyl Amino Purin to Spur the Growth of Callus and Squash in Cotyledon Melon (Cucumis melo L.). Buletin Teknik Pertanian. 14(2): 50-53

[6] Ariati, S.N. 2012. Induction of Cocoa Plant Callus (Theobroma cacao L.) On MS Media with Addition of 2,4-D, BAP and Coconut Water. Natural Science Journal. 1(1): 78-84

[7] Azizah, R. 2017. Growth of Liberika Coffee Callus Tungkal Jambi (Coffealiberica Var. Liberica Cv. Tungkal Jambi) with In Vitro Combination of 2,4-D and Kinetin. Thesis. Faculty of Agriculture, Jambi University.

[8] Chernova, L., K., Prokhorov M.N. and Filin Koldakov. 1975. Comparis on of the dedifferentiating effects of 2,4-D and 4-amino-3,5,6-tricloropicolinic acid on tissue of legumes and cereals. Fiz. Rast. 22: 170-175.

[9] Darwati,I. 2007. Callus Culture and Hair Root Culture of Purwoceng (Pimpinellapruatjan Molk.) To Produce Secondary Metabolites. Dissertation. ITB Bogor Postgraduate School. 
[10] Gardner, G.J.., R.B. Pearce and R.L. Mitchell. 1991. Cultivation Physiology (Translation of Herawati Susilo). UI. Press. Jakarta.

[11] George, E. F. 2008. Plant Propagation by Tissue Culture. Dordrecht: Springer.

[12] Gunawan, D, \& Mulyani, S,. 2004. Natural Medicine (Farmakognosi) Jilid I. Jakarta: Penerbit Penebar Swadaya

[13] Gunawan, L. W. 1998. Network Culture Techniques. Bogor: PAU IPB.

[14] Habibah. 2009. Effectiveness of Addition of Jasmonic Acid Elistator in Increasing Synthesis of Andrographolide Bioactive Compounds in Sambiloto Cell Suspension Culture. Biosaintifika. 1(1): 11-18.

[15] Hendaryono, D.P.S. dan A. Wijayani 1994. Network Culture Techniques. Introduction and Guidelines for Vegetative Modern Propagation. Yogyakarta: Kanisius

[16] Indah, N., dan Ermavitalini, D. 2013 . Induction of Nyamplung Leaf Callus (Calophyllum inophyllum Linn). In Some Combinations of 6Benzylaminopurine (BAP) and 2,4Dichlorophenoxyatic Acid Concentrations (2,4 -D). Surabaya. Journal of science and art pomits. 2 (1): $2337-3520$.

[17] Kardinan. 2005. Fragrant Commodity Essential Oil Producing Plants Full of Potential. Jakarta: Penerbit Agromedia Pustaka.

[18] Karjadi dan Buchory. 2008. Effect of Basic Media Composition, Addition of BAP, and Pikloram Against Induction of Shallot Buds. J. Hort.18(1): 1-9

[19] Lestari E.G dan I Mariska, 2003. Effect of various media formulations on regeneration of indica rice callus. Proceedings of the Plant Pilot and Biotechnology Research Seminar, 257-263. Bogor, 23-24 September 2003.

[20] Lim, Z., Anna P., dan Sobri Hussein. 2009. Callus induction of Ocimum sanctumand estimation of its total flavonoid content. Asian Journal of Agricultural Sciences.1 (2):55-61.

[21] Litz, R.E and D.J. Gray. 1995. Somatic embryogenesis foragriculture improvment. World Jour.Microbiol. And Biotech. 11 : 416-425.

[22] Mahadi, I. 2008. Production of multiple shoots (Goniothalamus umbrosus J. Sinclair) by using the hormone kinetin and BAP in vitro. Agriculture Dynamics.23: 34-36.

[23] Mahadi, I., Wan Syafi'i dan Yeni Sari. 2016. Induction of Kasturi Orange Callus (Citrusmicrocarpa) Using 2,4-D and BAP with in vitro method. Journal of Indonesian Agricultural Sciences (JIPI). 21 (2): 84-89.
[24] Mangun, H. M. S. 2002. Patchouli. Jakarta: Penebar Swadaya.

[25] Nobert O, Zolta S, Be'la Da'nos. 2007. Influence of Different elicitors on the sunthesis of anthraquinone derivatives in Rubia tinctorum L. cell suspension cultures. Science Direct. Dyes and Pigments. 77: 249-257.

[26] Nugroho, Adi. 2008. Bussnies Plan. Jakarta: Universitas Indonesia. NuryaniY., Hobir, dan Syukur C., 2006. Patchouli Breeding Status (Pogostemon cablin Benth.). Technological development TRO.15 (2).

[27] Rukmana, R.2003. Patchouli Agribusiness Prospects and Cultivation Techniques. Penerbit Kanisius Yogyakarta.

[28] Santoso, H. B. 1991. Plant Patchouli. Yogyakarta: Kanisius.

[29] Santoso, U. dan Nursandi. 2004. Plant Tissue Culture. Malang: UMM Press.

[30] Tu, et.al.2001. Picloram.Weed Control Methods Handbook, The Nature Conservancy

[31] Zulkarnain. 2009. Plant Tissue Culture: Propagation Solution for Cultivation Plants. Jakarta: Bumi Aksara 